\title{
Pengentasan Buta Aksara Melalui Pembelajaran Calistung Di Kampung Nanggou Distrik Sausapor Kabupaten Tambrauw Papua Barat
}

\author{
Zulkarnain Sangadji $^{1^{*}}$, Ihsan Febriadi ${ }^{2}$ Febrianti Rosalina $^{3}$ \\ 1, 2, 3 Universitas Muhammadiyah Sorong, Indonesia \\ *e-mail: zulkarnainums1@gmail.com
}

\begin{abstract}
ABSTRAK
Pemberantasan buta aksara adalah salahsatu bagian integral terkait pengentasan masyarakat dari kebodohan, kemiskinan, dan keterbelakangan, serta ketidakberdayaan dalam pengembangan kualitas sumber daya manusia di Indonesia. Distrik Sausapor sebagai Distrik yang berfungsi sebagai Ibu Kota Kabupaten Sementara Kabupaten Tambrauw menuntut masyarakatnya khususnya di daerah Pesisir yang masih memiliki Pendidikan rendah dan kemampuan berkomunikasi yang rendah dengan kemampuan Calistung yang masih sangat membutuhkan pemberdayaan, khususnya pembelajaran membaca, menulis dan menghitung. Sebagai Kabupaten yang memiliki jumlah penduduk Buta Aksara terbanyak di Papua Barat, tentunya Pembelajaran Calistung ini sangat perlu dilakukan. Hal ini tentunya akan berdampak positif terhadap kemampuan berkomunikasi masyarakat. Berdasar pada hal tersebut maka dilakukan kegiatan berupa pengentasan buta aksara melalui pembelajaran calistung (membaca, menulis, dan berhitung) secara berkelompok dengan tiga tahapan yang dimulai darin tahap persiapan, pelaksanaan hingga tahapan analisis data. Selanjutnya demi keberlanjutan kegiatan pemberdayaan masyarakat tersebut akan dipilih beberapa calon tutor yang akan melanjutkan kegiatan belajar kelompok yang telah dibentuk. Demi meningkatkan kemampuan berkomunikasi masyarakat, metode pembelajaran yang berbasis komunikatif dilakukan agar mampu melatih masyarakat dalam berinteraksi satu sama lainnya. Kemampuan aksara masyarakat diukur melalui pre test (sebelum kegiatan) dan post test (setelah kegiatan). Hasil kegiatan menunjukkan bahwa terjadi peningkatan kemapuan Calistung warga belajar setelah dilakukan proses belajar mengajar oleh tutor. Dimana kemampuan membaca, menulis, dan berhitung sebelum kegiatan adalah 20\%, 28\%, dan 19\% dan meningkat manjadi 84\%, 85\%, dan $78 \%$ setelah kegiatan. Adapaun kegiatan ini tidak akan berjalan lancer jika tidak ada Kerjasama yang baik dari berbagai pihak dan tentunya kesadaran belajar yang tinggi dari warga belajar harus diciptakan agar tujuan kegiatan bisa tercapai dengan baik.
\end{abstract}

Kata kunci: Buta Aksara; Calistung; Warga Belajar

\begin{abstract}
lliteracy eradication is an integral part related to alleviating society from ignorance, poverty and underdevelopment, as well as powerlessness in developing the quality of human resources in Indonesia. Sausapor District as a district that functions as the capital of the Regency while Tambrauw Regency demands its people, especially in coastal areas, who still have low education and low communication skills with Calistung's ability which still desperately need empowerment, especially learning to read, write and count. As a district that has the largest number of illiterate people in West Papua, of course this Calistung Learning is very necessary. This of course will have a positive impact on people's communication skills. Based on this, activities were carried out in the form of literacy alleviation through learning calistung (reading, writing, and arithmetic) in groups with three stages starting from the preparation stage, implementation to the data analysis stage. Furthermore, for the sake of sustainability of these community empowerment activities, several prospective tutors will be selected who will continue the group learning activities that have been formed. In order to improve the community's communication skills, communicative-based learning methods are used in order to be able to train people to interact with one another. Community literacy skills were measured through a pre test (before the activity) and a post test (after the activity). The results of the activity showed that there was an increase in the learning capacity of Calistung residents after the teaching and learning process was carried out by the tutor. Where the ability to read, write, and count before the activity was 20\%, 28\% and 19\% and increased to $84 \%, 85 \%$, and $78 \%$ after the activity. As for this activity, it will not run smoothly if there is no good cooperation from various parties and of course a high learning awareness from the learning community
\end{abstract}


must be created so that the objectives of the activity can be achieved properly.

Keywords: Illiterate; Calistung; Citizens Learn

\section{PENDAHULUAN}

Pendidikan sebagai fokus utama pengabdian KKN-PPM ini menjadi hal yang sangat mendasar yang mampu meningkatkan kesejahteraan masyarakat secara mandiri dan menjadi suatu perhatian lebih kepada masyarakat di Kabupaten Tambrauw khususnya di Distrik Sausapor karena mengingat masyarakat disana adalah rata-rata penduduk asli yang belum menyentuh Pendidikan. Tentunya hal ini bertolak belakang dengan tujuan pemerintah yakni wajib belajar 9 tahun. Venny (2010) menyatakan bahwa buta aksara menjadi salah satu faktor yang menghambat pembangunan sumber daya manusia. Persentase penduduk di Kabupaten Tambrauw yang belum menyelesaikan program wajib belajar 9 tahun sebesar $80 \%$ menjadi tolak ukuran terhadap tingginya jumlah penduduk yang buta aksara di daerah tersebut.

Oleh karena itu, lokasi kegiatan program pengentasan buta aksara melalui kegiatan pembelajaran membaca, menulis dan berhitung dipusatkan di Kampung Nanggou Distrik Sausapor di Kabupaten Tambrauw sebagai pusat kegiatan Program KKN-PPM yang dilaksanakan oleh Dosen dan mahasiswa Universitas Muhammadiyah. Hal ini juga telah disampaikan oleh Yohana sebagai pelopor tim Kegiatan Pemberantasan Buta Aksara di kabupaten Tambrauw, bahwa sebagian besar penduduk Tambarau selalin belum mampu membaca, menulis, dan menghitung, tetapi mereka juga tidak mampu berkomunikasi dengan baik.

Mengenyam pendidikan sekolah merupakan upaya penanggulangan buta huruf yang dapat dilakukan sejak dini. Melalui pembelajaran di bangku sekolah itulah angka penyandang buta aksara sebagai salahsatu permasalahan yang cukup panjang di Indonesia dapat dikurangi. Bahkan kemampuan Calistung juga merupakan kemampuan dasar yang wajib dimiliki oelah seseorang guna menunjang segala aspek kehidupan, seperti berkomunikasi dan bersosialisasi dengan baik. Bahkan kemiskinan, keterbelakangan, kebodohan dan ketidakberdayaan masyarakat bisa dihindari (Jessica dkk, 2017).

Pelaksanaan pendidikan keaksaraan dasar dimana warga belajar merupakan orang dewasa memerlukan pendekatan atau strategi khusus. Tutor harus mengetahui dan memahami tentang metode pendidikan orang dewasa atau andragogi didalam pembelajaran keaksaraan dasar. Dimana pendidikan orang dewasa berbeda dengan pendekatan yang dilakukan terhadap anakanak (Sutrisno, 2020). Faktor pendukung pendidikan keaksaraan dasar terdiri dari kemampuan tutor keaksaraan dasar, dukungan dari pemerintah pusat dan daerah, motivasi dari warga belajar dan Tersedianya sarana dan prasarana yang memadai (Sutrisno, 2020). Sedangkan menurut Sonbait (2020), kendala yang masih ditemui dalam program pembelajaran buta aksara adalah masih rendahnya minat atau partisipasi masyarakat pada beberapa kegiatan dan tingkat kemandirian pada kelompok sasaran juga masih rendah.

Berdasar pada permasalahan tersebut diatas, Tim pengusul KKN-PPM bersama Mitra yang bersedia menyediakan tempat kegiatan telah sepakat untuk bersama selama kurang lebih 1 bulan saling membantu menyelesaikan permasalahan pendidikan khususnya mengurangi jumlah penduduk buta aksara di Distrik Sausapor guna meningkatkan kemampuan berkomunikasi masyarakat. Dengan kemampuan berkomunikasi yang baik tentunya akan memberikan perubahan yang lebih baik secara pribadi bahkan secara bermasyarakat. Bahkan melalui pembelajaran calistung dalam pengentasan buta aksara ini, tentunya kemudahan informasi juga akan bisa dirasakan dan dimanfaatkan dengan baik oleh masyarakat di daerah tersebut guna menunjang taraf hidup yang lebih baik kedepan.

Sehubungan dengan uraian di atas maka tujuan kegiatan ini adalah memberikan pendidikan kepada masyarakat Kampung agar mampu membaca, menulis, dan menghitung sebagai langkah utama dalam memberantas buta aksara di Kampung Nanggouw. Diharapkan dengan adanya kegiatan ini juga dapat memotivasi masyarakat untuk mendorong anak-anak 
mereka melanjutkan pendidikan, sehingga angka putus sekolah di Kampung Nanggouw dapat dikurangi.

\section{METODE}

Adapun metode pelaksanaan pengentasan buta aksara program KKN-PPM yang dilakukan oleh tim adalah sebagai berikut:

1. Tahapan persiapan

Pada tahapan ini akan dilakukan beberapa tahapan persiapan berikut:

a. Sosialisasi kegiatan

Tim melakukan sosialisasi program kepada mahasiswa peserta KKN Universitas Muhammadiyah Sorong guna menyiapkan mahasiswa sebagai bagian dari pelaksanaan kegiatan ini (calon tutor).

b. Identifikasi dan pemetaan sasaran program

Tentunya sebelum melaksanakan program, terlebih dahulu tim melakukan survey ke lokasi kegiatan guna mengumpulan data mengenai jumlah calon peserta dan umur calon peserta guna menajadi pertimbangan dalam pembagian kelompk belajar.

c. Pembekalan calon tutor

Sebelum pelaksanaan kegiatan, akan dilakukan pembekalan mahasiswa calon tutor guna menyatukan ide dan tujuan kegiatan KKN-PPM. Dalam pembekalan tersebut akan disampaikan kondisi masyarakat tujuan serta calon tutor akan dibekali pengetahuan dan keterampilan proses belajar mengajar sesuai dengan prinsip pembelajaran buta aksara.

Sesuai dengan prinsip penyelenggaraan pendidikan keaksaraan, program pemberantasan buta aksara harus berdasar pada prinsip-prinsip pembelajaran keaksaraan fungsional yang meliputi: Konteks Lokal, Desain Lokal, Proses partisipatif, Fungsionalisasi Hasil Belajar, Kesadaran, Fleksibilitas, Keanekaragaman dan Kesesuaian hubungan belajar.

2. Tahapan Pelaksanaan

Tahapan pelaksanaan kegiatan terdiri dari:

a. Mengidentifikasi tema-tema local sebagai sumber belajar

Idenstifikasi tema Lokal menjadi salah satu upaya terbaik yang harus dilakukan dalam pengentasan buta aksara. Tentunya upaya tersebut dilakukan pada tahap pelaksanaan awal guna menunjang proses pembelajaran calistung. Tema Lokal pun akan membantu masyarakat untuk lebih mudah memahami materi calistung yang diajarkan. Contohnya, calistung yang berhubungan dengan hutan, pasar took sekitar dan tema Lokal lainnya.

b. Melakukan kontrak belajar

Kontrak belajar perlu dilakukan di awal pelaksanaan kegiatan. Karena tanpa kesepakatan antara tutor dan peserta, tentu kegiatan tidak bisa berjalan dengan baik. Jadi, mendiskusikan kontrak belajar berupa, jadwal dan lokasi kegiatan sesuai dengan yang disepakati bersama menjadi hal yang wajib dilakukan.

c. Menyusun program belajar

Selanjutnya, tim melakukan penyusunan program belajar awal, dengan bekerjasama topik pembelajaran sesuai dengan data yang telah dikumpulkan sebelumnya. Di tahapan ini juga, kebutuan administrasi kegiatan berupa absensi dan silabus pembelajaran disusun. Tetapi tentunya program pembelajarannya akan selalu menyeseuaikan dengan konteks masyarakat Lokal untuk menunjang kelancaran kegiatan pembelajaran.

d. Pemilihan pendekatan/metode pembelajaran

Pendekatan dan metode pembelajaran akan dipilih berdasarkan pada kebutuhan masyarakat sebagai perserta kegiatan. Sebagai tahap awal, penedekatan komunikatif dengan metode interaktif dan berbasis praktek akan dilakukan. Selanjutnya pemilihan pendekatan dan metode didasarkan pada situasi dan kondisi kegiatan pembelajaran.

e. Pelaksanaan proses pembelajaran calistung 
Proses pembelajaran calistung yang akan dilaksanakan oleh mahasiswa dilakukan minimal 3 kali seminggu.

f. Menyiapkan sumber/media pembelajaran

Sumber belajar dan media pembelajaran menjadi salah satu bagian yang tidak boleh terlupakan dalam kegiatan ini. Menumbuhkan minat dan ketertarikan belajar bagi masyarakat tentunya menjadi salah satu hal yang perlu menjadi perhatian tim. Oleh karena itu melalui pembuatan dan pemilihan sumber dan media pembelajaran harus dilakukan dengan semenarik mungkin. Tim akan bekerjasama menyediakan media pembelajaran yang menarik demi membantu pengikatan kemampuan calistung peserta pengentasan buta aksara. Sumber belajar yang tersedia di sekitar pun akan digunakan, seperti rumah, ternak, aktivitas masyarkat serta konteks sekitar lainnya.

g. Monitoring dan evaluasi

Monitoring dan evaluasi akan selalu dilakukan dalam setiap proses pembelajaran. Hal tersebut dilakukan untuk menjamin terlaksananya kegiatan dengan baik guna mencapai tujuan yang diharapkan. Monitoring dilakukan oleh pembimbing dengan secara langsung melihat proses belajar mengajar yang dilakukan oleh tutor. Di setiap pertemuan, tutor wajib menulis laporan mengenai kemajuan pembelajaran yang terjadi untuk mengetahui pecapaian hasil belajar peserta tiap proses pembelajaran dilaksanakan.

Adapun evaluasi pembelajaran peserta akan dilakukan di setiap pertemuan guna melihat perkembangan calistung masing-masing peserta. Dan untuk mengetahui perkembangan awal dan akhir peserta, evaluasi akan dilakukan di awal (pre test) dan akhir program (post test).

3. Tahapan Analisis Data

Analisis data ini diperlukan guna mengetahui keefektifan kegiatan KKN-PPM. Untuk mengetahui berapa jumlah peserta yang telah mampu membaca, menulis dan menghitung akan dilakukan perhitungan sebagai berikut:

$$
\frac{\text { jumlah peserta dengan buta aksara }}{\text { jumlah seluruh peserta pembelajaran buta aksara }} \times 100
$$

Pada tahapan ini, hasil evaluasi akhir pun akan di analisis dengan mempertimbangkan syarat tertentu bagi tiap peserta guna pemberian sertifikat calistung. Jika memenuhi syarat maka peserta tersebut akan diberikan sertifikat calistung yang menandakan bahwa peserta tersebut sudah bisa membaca menulis dan menghitung secara mandiri. Sedangkan bagi peserta yang belum memenuhi syarat, maka akan diberikan pembelajaran selanjutnya.

\section{HASIL DAN PEMBAHASAN}

Program pengentasan buta aksara yang dilakukan berjalan dengan lancar berkat dukungan dari berbagai pihak mulai dari pemerintah dalam hal ini Dinas Kebudayaan dan Pariwisata Provinsi Papua Barat, aparat kampung, serta lingkup masyarakat di lokasi sasaran kegiatan KKN-PPM. Masyarakat selaku warga belajar yang terlibat antusias mengikuti kegiatan, mulai dari kegiatan sosialisasi hingga kegiatan pembelajaran. 

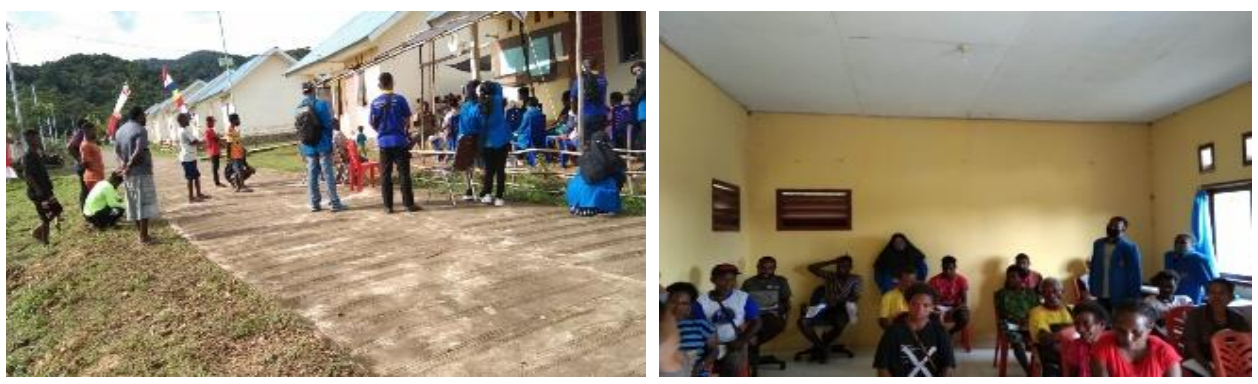

Gambar 1. Sosialisasi kegiatan KKN-PPM

Setelah dilakukan sosialisasi terkait kegiatan pembelajaran calistung kepada masyarakat, maka dilanjutkan dengan pendataan masyarakat sebagai calon warga belajar yang selanjutnya akan mengikuti kegiatan pembelajaran calistung yang dipandu oleh masing-masing tutor.
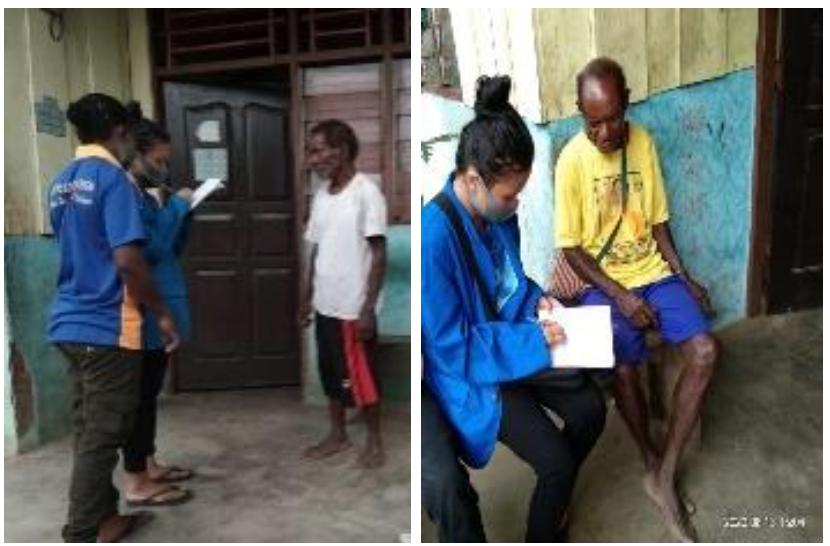

Gambar 2. Pendataan calon warga belajar

Berdasarkan kegiatan pembelajaran yang dilaksanakan selama satu bulan, maka kemampuan aksara membaca, menulis dan berhitung warga belajar diketahui melalui hasil pretest dan post-test yang telah diberikan. Data yang diperoleh disajikan pada Tabel 1.

Tabel 1. Hasil pre-test dan post-test warga belajar

\begin{tabular}{llcccc}
\hline \multirow{2}{*}{ No } & Indikator & \multicolumn{2}{c}{ Pre-test } & \multicolumn{2}{c}{ Post-test } \\
\cline { 3 - 6 } & & Total skor & $\begin{array}{c}\text { Rata-rata } \\
(\%)\end{array}$ & Total skor & $\begin{array}{c}\text { Rata-rata } \\
(\%)\end{array}$ \\
\hline 1 & Membaca & 241,67 & 20 & 1008,33 & 84 \\
2 & Menulis & 336,84 & 28 & 1021,05 & 85 \\
3 & Berhitung & 222,86 & 19 & 977,14 & 78 \\
\hline
\end{tabular}

Sumber: data primer, 2020

Kriteria nilai bagi warga belajar yang mengikuti penilaian akhir pembelajaran keaksaraan dan dijadikan acuan untuk memformulasikan nilai membaca, menulis, dan berhitung berdasarkan Panduan Penyelenggaraan dan pembelajaran Pendidikan Multikeaksaraan (2017). Berdasarkan hasil pres-test dihasilkan bahwa rata-rata kemampuan keaksaraan berada pada kategori kurang (dengan rentang nilai <54) dan setelah dilakukan post-test diakhir pembelajaran maka kemampuan keaksaraan berada pada kategori mampu (dengan rentang nilai 70-85). 

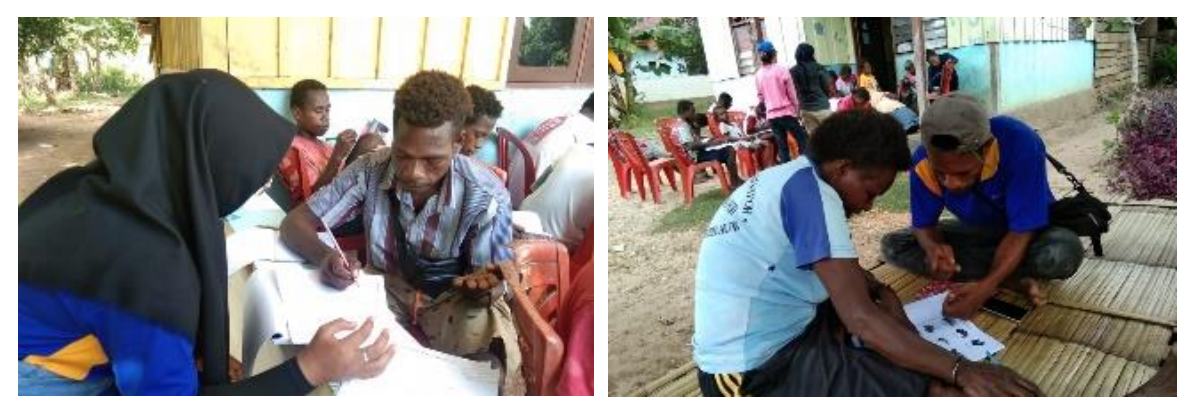

Gambar 3. Proses kegiatan pembelajaran

Pengukuran kemampuan warga belajar mencakup kemampuan membaca, menulis, dan berhitung. Yang dimaksud warga belajar dalam ini adalah mereka yang seharusnya berkewajiban mengikuti program penuntasan buta aksara atau masyarakat penyandang buta aksara sasaran garapan pemberantasan calistung (membaca menulis dan berhitung). Dimana sasaran utamanya adalah masyrakat yang masih berusia produktif ataupun lanjut usia yang masih berpotensial dalam menjaga kualitas hidupnya. Hal ini dilakukan karena warga belajar yang berusia lanjut, baik secara fisik maupun secara psikologisnya akan berbeda dengan warga belajar yang berada dibawah usianya (Mariyono, 2016; Utomo, 2013).

Indikator kemampuan membaca, menulis, dan berhitung disesuaikan dengan standar kompetensi keaksaraan tingkat dasar. Secara detail perbedaan masing-masing kemampuan di pengukuran awal (pre-test) dan akhir (post-test) dapat terlihat dalam Gambar 1, Gambar 2, dan Gambar 3.

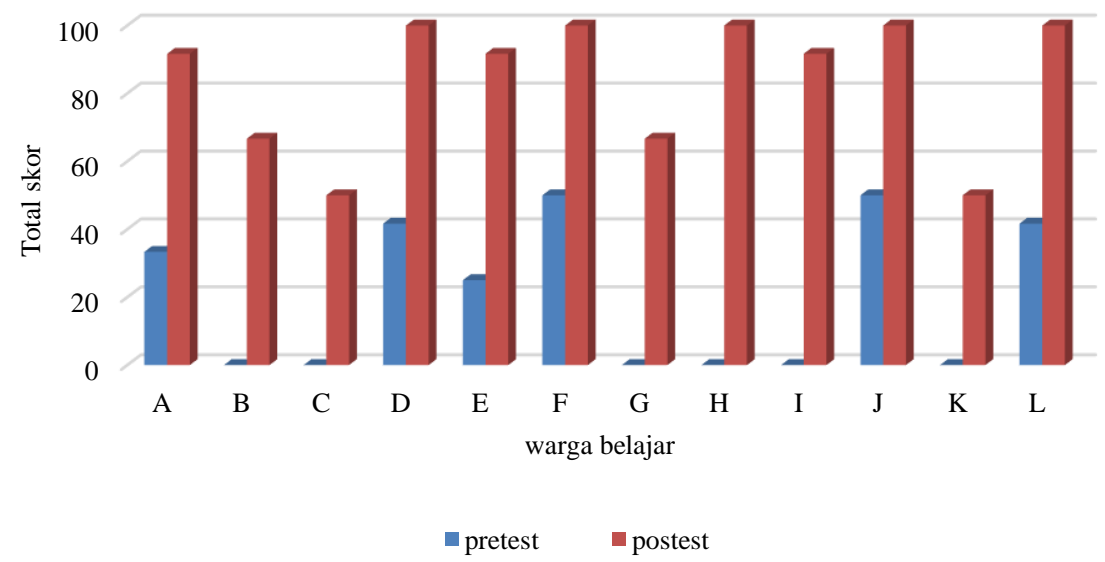

Gambar 4. Skor kemampuan membaca

Berdasarkan grafik pada Gambar 4 dapat dilihat bahwa rata-rata kemampuan membaca warga belajar sebelum dan setelah kegiatan mengalami peningkatan yang signifikan. Dimana kemampuan membaca warga belajar sebelum kegiatan terdiri dari berbagai masalah mulai dari belum mengenal huruf sama sekali, mengenal huruf tapi tidak mampu membaca rangkaian kata dan kalimat, mampu membaca kata tetapi masih terbata-bata dalam menyusun menjadi kalimat. Setelah dilakukan kegiatan proses belajar-mengajar, rata-rata warga belajar sudah mampu mengenal huruf hingga mampu membaca dengan benar, walaupun sebagian warga belajar masih harus dituntun untuk mengeja huruf. 


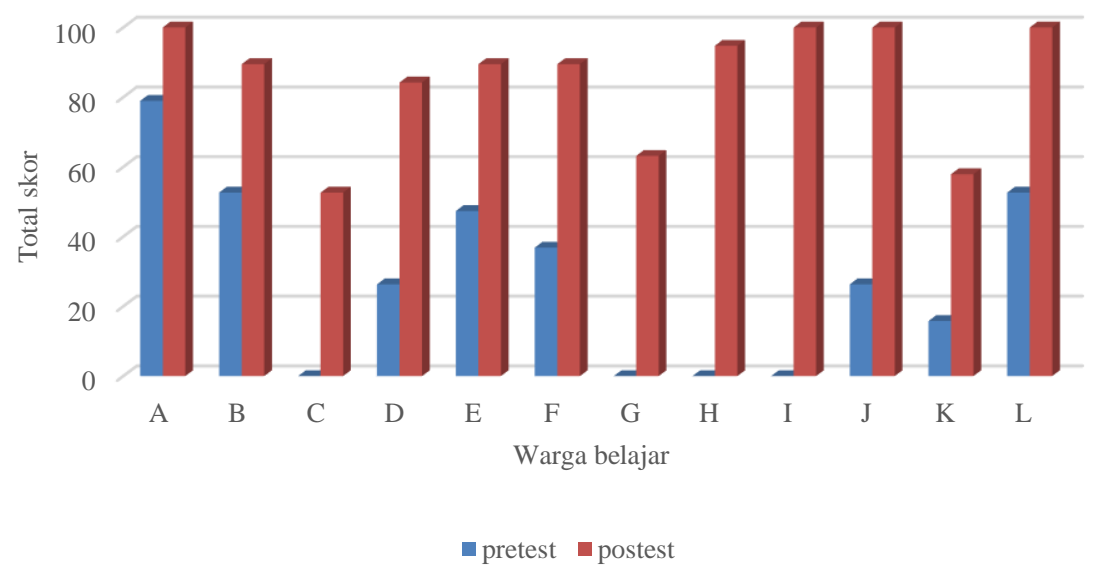

Gambar 5. Skor kemampuan menulis

Kemampuan menulis warga belajar berdasarkan Gambar 5 mengalami peningkatan dari tidak bisa menulis hingga mampu menulis dengan menyalin tulisan yang ada dikertas maupun dari pelafalan suara.

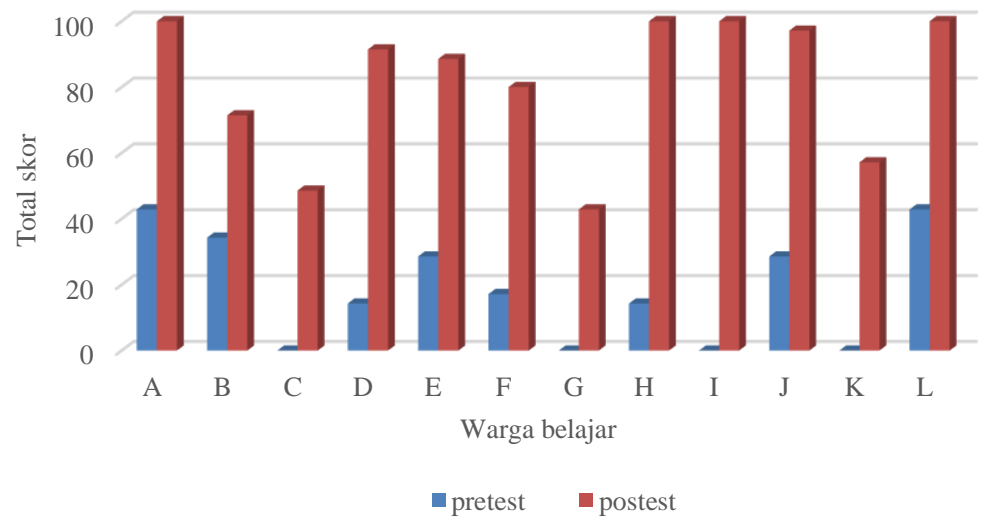

Gambar 6. Skor kemampuan berhitung

Kemampuan berhitung warga belajar berdasarkan grafik pada Gambar 6 tidak jauh berbeda dengan kemampuan membaca dan menulis. Rata-rata kemampuan warga belajar diawal pembelajaran hanya mengenal angka 1 sampai 10, bahkan beberapa warga belajar ada yang tidak mengenal angka sama sekali. Selain itu, rata-rata warga belajar belum mampu menguasai cara berhitung yang benar, sebagian besar hanya mampu menjumlahkan angka dengan dipandu langsung oleh tutor. Tetapi setelah kegiatan pembelajaran dilaksanakan, hampir semua warga belajar mengalami peningkatan berhitung yang lebih baik dari sebelumnnya, walaupun beberapa yang belum bisa berhitung diluar kepala.

Dengan dilaksanakannya program Pemberantasan Buta Aksara maka dampak sosial yang diharapkan terjadi pada kehidupan masyarakat yaitu masyarakat mampu berinisiatif dan memiliki kemandirian dalam kehidupannya sehingga tidak menggantungkan diri pada orang dan berpikiran untuk maju. Selain itu juga diharapkan masyarakat sudah memiliki kemampuan keaksaraan sehingga mampu melakukan berbagai kegiatan yang berhubungan dengan keaksaraan dan mampu mengakses informasi dalam bentuk tulisan seperti koran dan majalah (Hariadi, 2018).

Hasil dari program kegiatan pemberantasan buta aksara berbasis tutorial terpadu yang dilakukan oleh Amri (2017) menunjukkan bahwa kontribusi dari adanya kegiatan tersebut terhadap warga belajar berubah dari yang sebelumnya belum mampu membaca, menulis, dan 
berhitung menjadi mampu untuk membaca, menulis dan berhitung. Hal ini juga didukung oleh Quraisy dan Babo (2016) bahwa masyarakat yang dulunya buta huruf secara social sekarang mampu membaca, menulis, dan berhitung. Sedangkan jika ditinjau dari aspek ekonominya, masyarakat mampu menerapkan keterampilan fungsional yang telah dipelajari selama proses pembelajaran pengentasan buta huruf secara mandiri dalam meningkatkan kemampuan berwirausanya.

Berdasarkan hasil evaluasi yang dilakukan di setiap tahapan pembelajaran, terbukti bahwa program pemberantasan buta aksara yang dilakukan oleh mahasiswa bekerja sama dengan PKBM Harapan Bersama selama tiga bulan berhasil memberikan kemampuan membaca, menulis, dan berhitung bagi peserta dengan tingkat keberhasilan rata-rata di atas $70 \%$. Hal tersebut mengindikasikan bahwa program ini berhasil memotivasi masyarakat untuk lepas dari belenggu buta aksara (Jessica, dkk 2017; Yunus, dkk 2020).

\section{SIMPULAN}

Pelaksanaan KKN-PPM Pemberantasan buta aksara ini diselenggarakan dengan tujuan memberikan kesempatan dan pengalaman kepada mahasiswa untuk mengembangkan kompetensi yang ada pada mereka. Beberapa kesimpulan yang didapatkan antara lain:

1. Kegiatan pengentasan buta aksara tidak akan berjalan lancar jika tidak ada Kerjasama yang baik dari berbagai pihak mulai dari warga masyarakat hingga aparatur pemerintahan.

2. Kesadaran belajar yang tinggi dari warga belajar harus diciptakan agar tujuan kegiatan bisa tercapai dengan baik. Kemampuan membaca, menulis, dan berhitung sebelum kegiatan adalah $20 \%, 28 \%$, dan $19 \%$ dan meningkat manjadi $84 \%, 85 \%$, dan $78 \%$ setelah kegiatan.

3. Dalam pelaksanaan kegiatan pembelajaran diperlukan semangat kerja yang tinggi, baik tenaga, pikiran, kesabaran, keuletan dan sarana serta prasarana yang menunjang.

4. Mahasiswa yang terjun ke lapangan dan berbaur dengan masyarakat kampung akan merasakan kehidupan bermasyarakat serta mampu memberikan motivasi.

\section{UCAPAN TERIMA KASIH}

Terima kasih penulis sampaikan kepada Direktorat Riset dan Pengabdian Masyarakat Direktorat Jenderal Penguatan Riset dan Pengembangan Kementerian Riset, Teknologi dan Pendidikan Tinggi (Kemenristek Dikti) yang telah memberikan dana hibah pengabdian pada tahun 2020.

\section{DAFTAR PUSTAKA}

Amril, L.O., Firmansyah, W., dan Hartati, Y. (2017). Pemberantasan Buta Aksara Berbasis Tutorial Terpadu bagi Masyarakat. Qardhul Hasan: Media Pengabdian kepada Masyarakat, 3(2):146-152.

Hariadi, J., Bania, A.S., dan Hidayat, M.T. (2018). Pelatihan Membaca Untuk Penngentasan Buta Kasara di Wilayah Kota Langsa. Jurnal Vokasi, 2(2): 98-103.

Jessica, V., Halis, A., Ningsi, D.W., Virginia, G.F., dan Syahidah. (2017). Pemberantasan Buta Aksara untuk Peningkatan Kualitas Sumber Daya Manusia Masyarakat Sekitar Hutan Desa Manipi, Kecamatan Pana, Kabupaten Mamamsa. Agrokreatif, 3(2): 136-142.

Mariyono. (2016). Strategi Pemberantasan Buta Aksara Melalui Penggunaan Teknik Metastasis Berbasis Keluarga. Pancaran, 5(1): 55-66.

Sonbait, L. Y., Wambrauw, Y. L. D., \& Mulyadi, . (2020). Efektivitas Program Penuntasan Buta Aksara (Pba) Dalam Mendukung Pengembangan Pertanian Dan Ekowisata Melalui 
KKN-PPM Di Kampung Anggra Distrik Minyambouw Kabupaten Pegunungan Arfak. Jurnal Dinamika Pengabdian (JDP), 5(2), 162-170.

Sutrisno. (2020). Pembelajaran Keaksaraan Dasar PKBM Bina Sekar Melati di Desa Triharjo, Kecamatan Pandak, Bantul. DIKLUS: Jurnal Pendidikan Luar Sekolah, 2(4): 135-146.

Quraisy, H dan Babo, R. (2016). Pemberdayaan Masyarakat Desa yang Buta Huruf. Jurnal Equilibrium Pendidikan Sosiologi, 3(2): 213-222.

Utomo, F.H. (2013). Penuntasan Buta Aksara di Desa Sine Kecamatan Kalidawir Kabupaten Tulungagung Menuju Peningkatan Kualitas Hidup Masyarakat Pesisir. J-ADIMAS (Jurnal Pengabdian kepada Masyarakat, 1(1): 1-4.

Venny, A. (2010). Manual MDGs untuk Anggota Parlemen di Pusat dan Daerah. Jakarta (ID).

Yunus, MS, N.H., Andriani, dan Nurhidayah. (2020). Upaya Pemberantasan, Buata AKsara Melalui Pelatihan Membaca Menulis Berhitung (CALISTUNG) di Kampung Pendidikan. Jurnal CARRADDE: Jurnal Pengabdian kepada Masyarakat, 2(2): 139-144 